\title{
AN ODE TO BLACK BRITISH GIRLS
}

\author{
BLACK BRITISH FEMINISM, BLACK GIRL \\ SURREALISM, AND MICHAELA COEL'S \\ CHEWING GUM
}

Jeanelle Hope

Texas Christian University

j.hope@tcu.edu

\begin{abstract}
This article delves into Michaela Coel's Chewing Gum, examining how the cultural text builds upon Black feminist media discourse, and intimately grapples with the nuances of Black women's sexuality while explicitly challenging misogynoir. This work illustrates how Coel is helping develop a Black British cultural aesthetic that centers Black women's liberation, specifically from an African immigrant perspective, by using satire, all the beauty, pain, and struggles that come with \#blackgirlmagic, eccentric adornments, and 'awkward' ostentatious characters that at times play into racist images and tropes of Black womanhood to expose the absurdity of life in an anti-Black, sexist, and xenophobic society. In sum, this article understands Coel's work in Chewing Gum to be Black girl surrealism - the intersection of Afro-surrealism, British dark comedy, and Black feminism.
\end{abstract}

Keywords: Black British Feminism, Afrosurrealism, Black British television

\section{Introduction}

In the opening scene of Chewing Gum (2015-2017), Tracey Gordon, a Black British millennial (played by Michaela Coel), breaks the fourth wall, repugnantly decrying, "my mum was gonna name me Alyssa, which means sweet angel in Indian. But when I came out she looked at me and called me Tracey. Tracey. I mean it sounds like I eat bacon sammies or have sex in the back of the bus. I don't eat pork, man! And I don't want to have sex with my boyfriend in a bedroom." During this opening monologue Tracey's boyfriend, Ronald, a closeted gay man and devout Christian, is praying for the couple's chastity. Meanwhile, Tracey's subconscious is playing out graphic scenes of the two awkwardly grinding on each other while fully clothed. During this scene Tracey provides a glimpse into her ongoing and direly unwanted sexual repression, sharing that her frequent lustful dreams have caused sexual arousals to manifest in the form of uncontrollable nose bleeds. Within the first two minutes of the show, Coel - lead actress, writer, and creator of Chewing Gum - signals to the audience that they are in for a melodramatic and irreverent show that spares little to the imagination. Chewing Gum unapologetically holds up a mirror into Black girlhood and racial politics in Britain. 
Unlike the U.S. where Black television and film projects have been buoyed in recent years by calls for diversity in Hollywood, and social media campaigns like, \#oscarssowhite and \#representationmatters, dynamic Black-led and centered shows in the U.K. remain grossly underdeveloped. ${ }^{1}$ Aside from the 1990 s classic sitcom, Desmond's (1989-1994), British-Nigerian sitcom, Meet the Adebanjo's (2012-), award-winning BBC thriller starring Idris Elba, Luther (2010-), and the recently released Amazon Prime and Steve McQueen produced mini-series, Small Axe (2020), there have been few British shows that have chronicled the Black British experience or even provided an avenue for Black Brits to serve as dynamic lead characters. However, Coel's Chewing Gum is truly in a lane of its own. The show goes beyond the bounds of increasing representation and diversity in British television.

Through her works - Chewing Gum, which will serve as the anchoring text for this article, and I May Destroy You (2020) - Coel has not only thrust discussions of British racial politics, anti-blackness and misogynoir into the fore, she has dared to intimately contend with sexual assault on screen, and vividly tell the stories of working-class Black British people.

Using textual and discourse analysis the essay explores the struggles, career trajectories, and current wave of Black British actresses in television and film that are making their mark in Hollywood. With few opportunities for Black British actresses at home, and Europe more broadly, I examine how Black British actresses are thriving despite competing for roles that largely reflect the Black American experience. I engage current, yet problematic, industry discussions on 'colour-blind' casting that have shaped the complexity and availability of roles for Black British actresses in British television and film. From this broader discussion on Black British actresses, I delve into Chewing Gum to analyze how the show moves beyond calls for representation and diversity by tackling major strands of Black British feminism, including Black women's sexuality and the erotic, political blackness, misogynoir, and colourism. Thirdly, I trace how Chewing Gum draws on and reimagines Afrosurrealism through British dark humor, self-reflexivity, and Black girl aesthetics to create a new iteration of Afrosurrealism - Black girl surrealism - that explicitly centers Black girlhood and womanhood.

\section{The Rise of the Black British Actress}

During the 2018 Edinburgh TV festival, Michaela Coel delivered the distinguished MacTaggart Lecture. For nearly sixty minutes Coel gave a comedic, yet incredibly heartfelt and vulnerable speech detailing her upbringing in a working-class and predominately immigrant neighborhood in London. To a predominately white crowd of television industry professionals, Coel spoke of being incessantly ridiculed for the size of her lips and skin color in school, hypersexualized by her white peers, and shared what it felt like being the only Black girl in drama programs and regularly reduced to racial slurs. Towards the latter part of the lecture she recounted being conditioned to never accuse a producer or agent of being racist, no matter how many racist tendencies and patterns they acted out. She would in turn suggest that they may be "thoughtless," which she said was also met with contestation, reflecting, "but if you're not racist, or thoughtless about race, what other thing can you be?" The aforementioned comment came about after sharing her experience while on set filming Chewing Gum during a day that was colloquially referred to as "Trailer-Gate." Coel recalled, "I approached the trailers to find five actors and actresses ranging in tones of brown and black, including the woman who plays my mother, bound up in one third of a trailer... the second trailer was occupied by an actress, looking like privileged piggy in the middle, and the third was mine, the writer."2 After witnessing this inequity, Coel scolded one of the show's producers shouting, "you know what that looks like don't you? Like a fucking slave ship!"3 This was certainly not Coel's first nor last time speaking out about the racism she experienced and witnessed in the television industry.

Coel's critical remarks were nothing new for the industry. Just twenty-one years earlier, Marianne Jean-Baptiste, a veteran Black British actress, accused Simon Perry, Chief Executive of British Screen, for deliberately excluding Black actresses at the Cannes Film Festival that year. Jean-Baptiste, who had been nominated for a BAFTA, Golden Globe and Academy Award for her work on Secrets and Lies (2015-2016) that year lodged, 
When I was told that British Screen had invited a group of young actors out to Cannes, I just burst into tears because I thought this is so unfair. It was a snub. What more do they want? If you think about it, I made history. Not only was I the first British woman to be nominated for an Oscar, I was the first black British person. I see myself as British and I want to be celebrated in Britain... I don't want to sound like someone who has a chip on their shoulder. But if you keep quiet nothing will ever change and nothing will ever be done about it. ${ }^{4}$

As Steven Bourne lays out in Black in the British Frame: The Black Experience in British Film and Television, JeanBaptiste's story and the invisibility of Black British actresses is one that has persisted for decades. Beyond the television and film industry, this act of erasure is also perpetuated amongst film and television historians. ${ }^{5}$

In the face of such systemic racism within the television and film industry, over the last twenty years Black British actresses have found much success overseas, and are dominating Hollywood. While the U.S. certainly has its own storied history (and present) of marginalizing Black actresses, Black character roles and films that address race head-on have certainly been much more plentiful in U.S. television and film in comparison to Europe. ${ }^{6}$ Because of the availability of greater roles, especially those with more dynamic character development, in the U.S., many Black British actresses have adopted a common trajectory - undergoing rigorous acting training in the U.K., often with a short stint at the West End Theatre or another professional theatre stage appearance, and crossing-over to Hollywood soon after, at times bypassing the British television and film circuit altogether.

This has certainly been the case for a number of veteran and younger Black British actresses, like Sophie Okonedo, who made her debut in the British coming-of-age feature film, Young Soul Rebels in 1991, and later starred in a production of Troilus and Cressida at the Royal National Theatre in 1999. However, Okenodo's breakout role, which earned her an Academy Award nomination, was a Hollywood produced film about the Rwandan genocide, Hotel Rwanda (2004). The film catapulted her career and she has since starred in a string of American films, including The Secret Life of Bees (2008), Broadway plays, and a few British television and film productions. Jean-Baptiste and Okonedo have helped blaze a path for younger Black actresses like, Cynthia Erivo, Nathalie Emmanuel, Freema Agyeman, Ashley Madekwe, Susan Wokoma, and a host of others, whose careers took off after finding success in Hollywood.

Following the 2020 \#blacklivesmatter protests in London and other parts of the U.K., a group of BAME actors and filmmakers circulated a proposal calling on Oliver Dowden, U.K. Secretary of State for Digital Culture, Media and Sport, as well as broadcasters and film studios, to make a real commitment to tackling systemic racism and ridding itself of 'weak excuses' which reinforce the notion that non-white stories are too "risky." David Oyelowo, Noel Clarke and other Black actors and filmmakers, the proposal vividly detailed how Black filmmakers and actors have been "shoved into a box that requires them to be BAME specialists" all the while being subjected to tokenism in their roles within the industry, and often confronted with demeaning white co-workers. ${ }^{8}$ Moreover, the proposal provided concrete action items that the industry and government could adopt to address systemic racism in the industry head-on, including, (1) increasing the number of Black and Asian TV commissioners, (2) developing a targeted recruitment process, (3) improving workplace monitoring, (4) creating an independent procedure for workplace grievances, and (5) instituting a mentorship program aimed at helping mid-level workers advance to more senior production roles. ${ }^{9}$

Unlike the Hollywood film and television industry, and its growing digital streaming rivals (i.e. Netflix, Hulu, Amazon, and Apple TV), which are largely financed and managed through private investors and major studio corporations, much of the British television and film industry is publicly-owned, overseen and funded by the Department for Digital Culture, Media and Sport and the British Film Institute, a charitable organization sponsored by the Department for Digital Culture, Media and Sport. The BBC, British Film Institute, and Channel 4 are all funded via a combination of national lottery funds, television licensing and taxes. This funding and oversight structure allow for a large segment of British television to avoid being beholden to shareholders and corporations, and attempts to evade the prioritization of profit, in lieu of "public value."10 Subsequently, 'public value' and 'public service' are mission pillars of the British television and film industry. However, with the lack of diverse representation within the British film and television 
industry, we must consider what public does the industry seek to engage and serve? In response to the 2020 letter from BAME actors and filmmakers, the BBC committed to spending $£ 100 \mathrm{~m}$ of its television budget developing "diverse and inclusive content" and required $20 \%$ of employees working on new television projects to be from diverse backgrounds. ${ }^{11}$ While these actions certainly allude to a potential for belated progress within the industry, the reality is that many Black actresses continue to turn to Hollywood or are left with few opportunities for work in the U.K. Moreover, many of the roles Black actresses have been cast for in the U.K. often rely upon a multicultural cast to create shows that have largely ignored U.K. racial politics and exist in a post-racial setting.

Popular shows like Casualty (1986-) and Law \& Order: U.K. (2009-2014), which have helped launch the careers of many Black British actresses, including Nathalie Emmanuel, Nina Toussaint-White, and Adelayo Adedayo, often feature Black women characters that exist in a world where race is seldom discussed and their blackness and Black womanhood is often not integral to character development. Philippa Giles, former Executive Producer of BBC's Luther, spoke of this trend in U.K. and European television as "colour-blind casting." Giles believes writing characters that could be portrayed by someone from any race was part of Luther's success, while also admitting the show's failure to reflect social issues of the country. Giles' comments and Luther's inability to speak to the U.K.'s racial reality is reflective of a larger trend within British television. Since 2016 colour-blind or "rainbow casting" has become a norm across British publicly-funded film and television projects, especially in period dramas, as it directly responds to critiques of public funding not being equitably applied to support BAME actors and projects, and meets the BFI and BBC's recently implemented socially-conscious criteria for casting. ${ }^{12}$ As Christine Geraghty argues, while casting for the public good is becoming more common, the contradictions still remain." ${ }^{13}$ By simply ignoring race and adopting colour-blind casting, British television will never fully be able to substantively grapple with the material realities and complex experiences of people of color in the U.K. Furthermore, colour-blind casting is not equivalent to an inclusive and anti-racist casting process. If art is meant to imitate life, then surely erasing the racial backgrounds from characters is a gross misstep.

Acutely aware of both the primary trajectory for Black British actresses and systemic racism in the television industry, both at home and abroad, Michaela Coel's work is so audacious because it challenges these issues head-on. Frequently serving as both a writer and actor, Coel often creates projects that are inspired by her own lived experience. She brazenly confronts systemic racism in the U.K., and centers Black girlhood and Black feminist politics. Her refusal to perfect an American accent is an intentional act of resistance rooted in a love and commitment to the Black British experience and telling the stories of her community. Aside from major recent contributions made by Steve McQueen and Idris Elba, Coel has helped reshape contemporary conversations on race and gender in the U.K. through her television projects - Chewing Gum and I May Destroy You.

\section{Black British Feminism \& Political Blackness in Chewing Gum}

Michaela Coel's Chewing Gum first debuted as a play at The Yard Theatre, London in 2012 under a similar moniker, Chewing Gum Dreams. Unlike the television show, the one-woman play centered around the life of 14-year old Tracey Gordon, who Coel characterized as "that loud annoying girl at the back of the bus," and was much more of a an early coming-of -age narrative reflection on teenage angst and puberty, and Gordon's struggle to juggle friendships, often complicated by racial and cultural tensions, and her mother's strict religious background. ${ }^{14}$ The television show debuted in October 2015 on E4 with a 24-year old-Tracey Gordon struggling to transition into adulthood. Gordon, still living at home in the working-class Andover Estate community with her sanctimonious mother and younger sister, works at a local convenience store, and spends much of her time focused on exploring her sexuality and interracial dating. Also, at the center of Tracey's life are her close friends and neighbors, Candice and Ola, who frequently enable her misadventures, boundless curiosity, and poor decision-making. 
Throughout the two seasons of Chewing Gum, Coel engages several central themes of Black British feminism, and Black feminism more broadly, including, Black women's sexuality and pleasure, challenging misogynoir and colorism, and the development of class, racial, and queer solidarities as a tool of survival and resistance. Black feminism, as espoused by Angela Davis, bell hooks, Kimberlé Crenshaw, among other pioneering Black feminist scholars, critically interrogates the intersection of race, class, and gender, unraveling how Black women have been oppressed and discriminated within society via structural inequalities and systems, like capitalism, patriarchy, and racism. Black feminism challenges mainstream discourse and media to recognize Black women's experiences and thought, and calls upon Black women to continue to actively resist gender and race-based oppression. More radical formations of Black feminist thought couple gender and racial oppression with economic oppression to illustrate how capitalism has further exacerbated the material realities of Black women. ${ }^{15}$ Black feminism also prioritizes Black women's pleasure while upending the history of Black women being perceived as hyper sexual jezebels. Black feminist scholars, like Shoniqua Roach and Jennifer Nash, reimagine and ascribe new meanings to Black women's genitalia and eroticism by moving beyond discourse on Black women's bodies and pleasure being inextricably linked to sexual deviance, in turn foregrounding new frameworks to read Black women's harnessing and performance of the erotic as a tool for liberation, and resistance to "racialized gendered sexual subjection."16 As Francesca Sobande uncovers in her work, Black feminism has shaped millennial depictions of Black women in television, specifically through projects like Issa Rae's Insecure (2016-) and Coel's Chewing Gum. Sobande's analysis of the two shows doesn't merely ascribe to the notion that an exploration of Black womanhood equates "Black feminist media." In fact, she argues that they at times (more so for Insecure) represent a Black post-feminist possibility. Black feminist politics, thought, critiques, and themes manifest in Chewing Gum's character development and relations, styling, the overall setting, and Coel's own personal politics around ownership and creative agency.

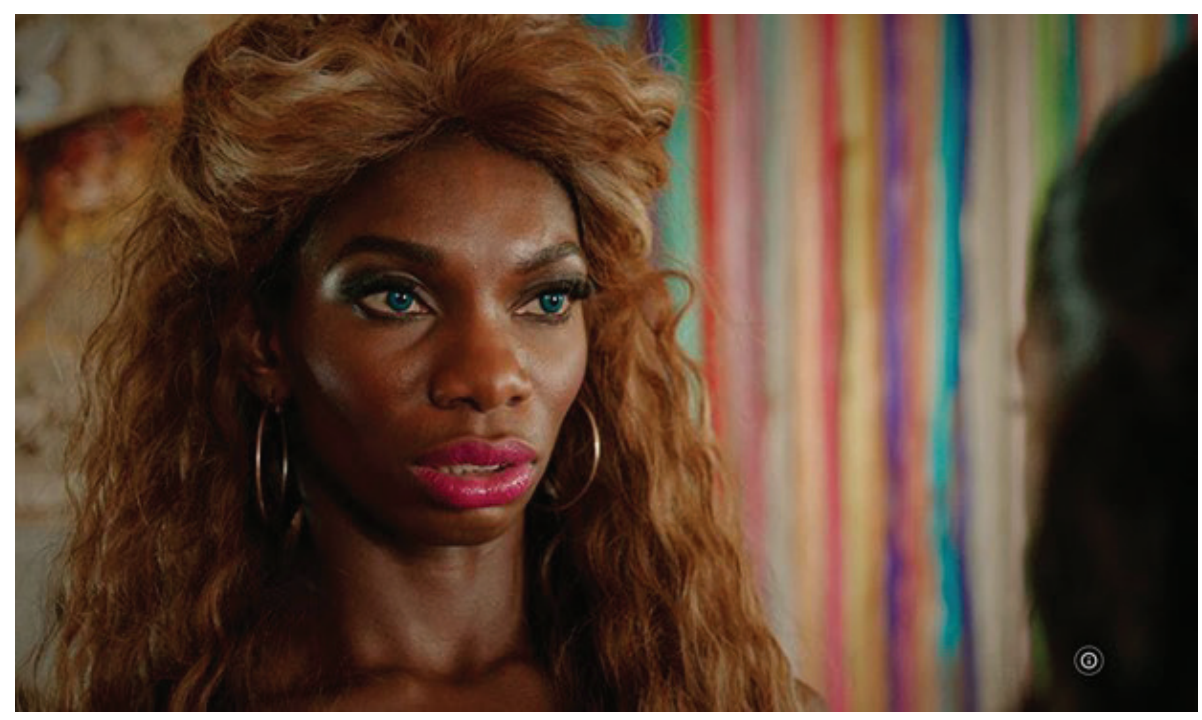

Figure 1. Season one episode one of Chewing Gum. Tracey has just received a makeover by her best friend, Candice (Source: imdb.com).

In Chewing Gum, Tracey's interest in exploring her sexuality, despite her mother's wishes for her to maintain celibacy, serves as the show's most prevailing and comical narrative. Much of the show's first season is filled with scenes of Tracey drifting off and imagining her own vibrant sex-life. In the show's opening scene, Tracey imagines herself and Ronald dry-humping and licking each other's faces—what she perceives as a major sexual act, and her primary understanding of sexual intimacy. Because of her limited sex education and stunted social development, Tracey's exploration of her sexuality is riddled with misinformation regarding sexual health and anatomy, and awkward missteps that make sex less of a seamless intimate act for her partners, and more of a moment of extreme second-hand embarrassment. In an effort to come across as more appealing to Ronald during their upcoming date, Tracey is given 
a makeover by one of her closest friends, Candice. Her new look includes an all-black ensemble complete with a bedazzled bustier, a highly pigmented made-up face of blue eyeshadow and contact lenses, and rosy pink lipstick that stand-out on Coel's dark brown skin and strikingly defined features; this of course is all capped off with a rather stiff dirty blonde wig to which Tracey responds, "I love it, it's like Beyoncé." As one could imagine, Tracey shares little resemblance to Beyoncé. In this scene, Tracey's new look acts as a mirror to frame and perform the absurdity of white beauty standards. As Candice completes Tracey's new look, which is met with confusion, she offers her some advice on how to coax Ronald into having sex with her, including puckering her lips while batting her eyes dreamily, and if all else fails, "just sit on his face." Tracey's new look is met with complete disgust and rejection. She desperately begs, "just show me that you want me...just rub the private parts on my private parts... just give me one kiss." A repugnant Ronald, still clinging onto his religious beliefs to thinly veil his closeted queer identity, responds to Tracey's efforts by ending their relationship. Later that evening, Tracey attends a party at Candice's flat where she laments, "he threw me out... he makes me feel like a freak for expressing myself like what I want to do is wrong... I express what I want and he goes ape shit." However, this moment of rejection is short-lived, as Tracey soon lives out all her wildest, yet underdeveloped, sexual fantasies with Connor, a white neighbor that she recently began lusting over following an encounter outside their building.

In her landmark work, When Chickenheads Come Home to Roost: A Hip-Hop Feminist Breaks It Down, Joan Morgan gave language to Black women's sexuality and expression of eroticism through their paradoxical relationship with hip-hop - a genre that many Black women had long written off as misogynist and anti-feminist. Morgan named this entanglement Black women have with the hyper sexual and degrading, yet erotic, verses in male-dominated hip-hop as "fucking with the grays."17 She defined the "grays" as this area where women who maintained a set of feminist sensibilities and politics were still drawn to the allure of hip-hop because they found those same male voices to be arousing. Moreover, they were especially drawn to how hip-hop often explicitly named the erotic, something women have been socially conditioned to suppress for fear of being perceived as sexually deviant or promiscuous.

Tracey is unafraid to express her eroticism and she helps shift notions of what it means to be "freaky." Patricia Hill Collins notes, "as the boundaries of race, gender, and sexuality soften and shift, so do the meanings of freaky as well as the practices and people thought to engage them."18 In other words, Tracey exists as this highly erotic character that is very much in touch with her own sexuality without being reduced to objectification or a hyper sexualized and racialized trope, which has comprised much of the way Black women's perceived sexuality has been portrayed in television, often for the male gaze. Nor does Tracey engage in a politics of respectability when it comes to her sexuality, another common trait for Black women characters, as respectability is often used to subvert the hypersexuality ascribed to Black women's bodies. Her sexuality is her own; and in a radical expression of her sexual agency, Tracey prioritizes her own pleasure, not that of her partners, nor the wishes of her mother and Christian faith. What makes Coel's portrayal and development of Tracey so intricate from a feminist lens is that sexuality is not necessarily tied to steamy sexual acts. Because of her naivete, much of Tracey's sexual interest manifests as a gawkish exploration of intimacy and her struggle to discern what a healthy relationship and sex life should look like. This accounts for a large amount of Tracey's awkwardness, and Coel does an exceptional job of staging Tracey's failures, misgivings, and naivete in a way that is still relatable to Black millennial women audiences. ${ }^{19}$ Tracey's sexual persona - which constantly shifts between assertive and hypersexual to cool and whimsical, and at times sexually adverse - is used as a tool to explore her broader identity and social categorization. ${ }^{20}$

In the opening scene of season one episode two, Tracey, staring directly into the camera, laments, "I always thought white people were bad kissers and it's not their fault, it's just that they've got really small lips and they can't embrace the challenge of lips like mine." Beyond engaging Black women's sexuality, pleasure, and the erotic, Chewing Gum also interweaves discussions on Black women's body politics, misogynoir, and challenges traditional notions of beauty. Coel's body and beauty is often described as "bold" and "sharp," a nod to her chiseled bone structure, full lips and nose, low-cut 4C hair, and rich dark skin, all of which certainly shape Tracey's character development, and are leveraged in Coel's acting to draw further attention. Standing opposite many of her intimate partners and peers, Tracey is often the only Black woman or darkest person in the frame. Coel makes Tracey seem both larger-than-life 
and like a shy adolescent school girl through her melodramatic facial expressions and body movements. Throughout the series there are a number of scenes and throwaway lines, like the aforementioned, where Tracey calls attention to her body and its stark contrast to her peers, often using these moments to decenter British whiteness and traditional notions of beauty. While much of Tracey's character is based on Coel's own lived experience, Tracey also functions as an intentional counternarrative and critique of how Black women have historically been portrayed within popular culture, or what Moya Bailey poignantly captured as misogynoir - the intersection of anti-blackness and sexism. ${ }^{21}$ Bailey's coining of the term emerged in direct response to the frequency in which misogyny has been explicitly directed towards Black women in popular culture. In a 2019 interview with Essence, Coel shared her own battles with misogynoir while filming Chewing Gum, she reflected, "some people thought I was too ugly to be on TV...there were people who said, 'I couldn't watch because of your face."'22 Drawing on Maxine Craig and Shatema Threadcraft's work, historically, Black women have always been excluded from the dominant beauty ideal. Moreover, the Black female body has often been a contested site of power marked by centuries of sexual violence and coerced sterilizations. ${ }^{23}$ This history and fraught body politics has also shaped the types of roles that have been readily accessible for Black women, with even fewer roles for Black women with darker skin complexions.

Cultural and media studies scholars, like Imani Cheers and Marquita Marie Gammage, ${ }^{24}$ have long examined the intersection of "race, class, gender, representation, media ownership and audience engagement," detailing how Black women have often been relegated to television and film roles that play into historical tropes like, mammy, sapphire, and jezebel. Conversely, in her work, The Evolution of Black Women in Television: Mammies, Matriarchs and Mistresses, Cheers argues that because of the increase of Black women in media, specifically as directors, producers, writers, and showrunners, Black women's representation in television has undergone a major cultural shift. ${ }^{25}$ Tracey, Chewing Gum, and Coel's body of work overall, are reflective of this trend. In addition to Tracey's written character development, her costuming and adornments also help in the centering of the Black female body and beauty. Throughout the series Tracey often dons no fewer than two high-colored and/or patterned articles of clothing, usually long-sleeved sweaters or shirts, and skirts of a modest length. She keeps her hair in two simple plaits, and wears little make-up, aside from a few episodes where she is going to a special event or date, and in that case her make-up is often highly pigmented and gaudy. Tracey's overall aesthetic, which has a Lisa Frank kitsch school girl veneer, ensures that she is at the center in each scene while not mimicking any hyper-sexualized tropes. Moreover, the contrast of her ostentatious costuming, and demure make-up and hairstyling help accentuate her physical blackness and prominent facial features. Tracey's overall aesthetic is designed to constantly maintain the audience's gaze and stand in contrast to the show's white characters. The character costuming and styling is also an integral part of the show's satirical shtick and Black girl surrealist cultural aesthetic, as will be explained below. A similar kind of styling is also echoed in several of the women of color and queer characters in the series. It is through styling that Chewing Gum challenges dominant beauty ideals and how racialized bodies are presented in British television.

Tracey's friendship with Candice, a mixed-race South Asian and white woman, is also another significant element of Chewing Gum's Black feminist, more specifically Black British feminist, lens. Living in what appears to be a predominately white working-class estate, Candice often helps Tracey navigate racial tensions and has been integral to her identity development. During her shift at a local convenience store, Tracey is visited by Candice and the two begin to talk about Tracey's budding relationship with Connor. As Candice challenges Tracey about her interest in Connor after she fumbles through answering basic questions about his life, unbeknownst to Tracey, Connor's mother is just a couple of feet away attempting to steal baby food. As his mother approaches the check-out counter where both Tracey and Candice are standing, she continues to take items from the counter. In an effort to distract the two from her shoplifting, she rambles, "Did you hear Karly Raven got pregnant by a Somali? Yeah, one of them piratelooking Somalians that look like a pirate. Are Somalians Black? I've never been too sure. I suppose there's different types of Black. Somalis look a little mixed-race but like something went wrong." Both Candice and Tracey look awkwardly at each other and struggle to respond to the racist and confusing ramblings. After Tracey points out that there are cameras around the store, Connor's mother empties the stolen goods from her bag and leaves. Candice turns to Tracey and says, "you should see her son." At which point Tracey is left dismayed, questioning her newfound relationship. 


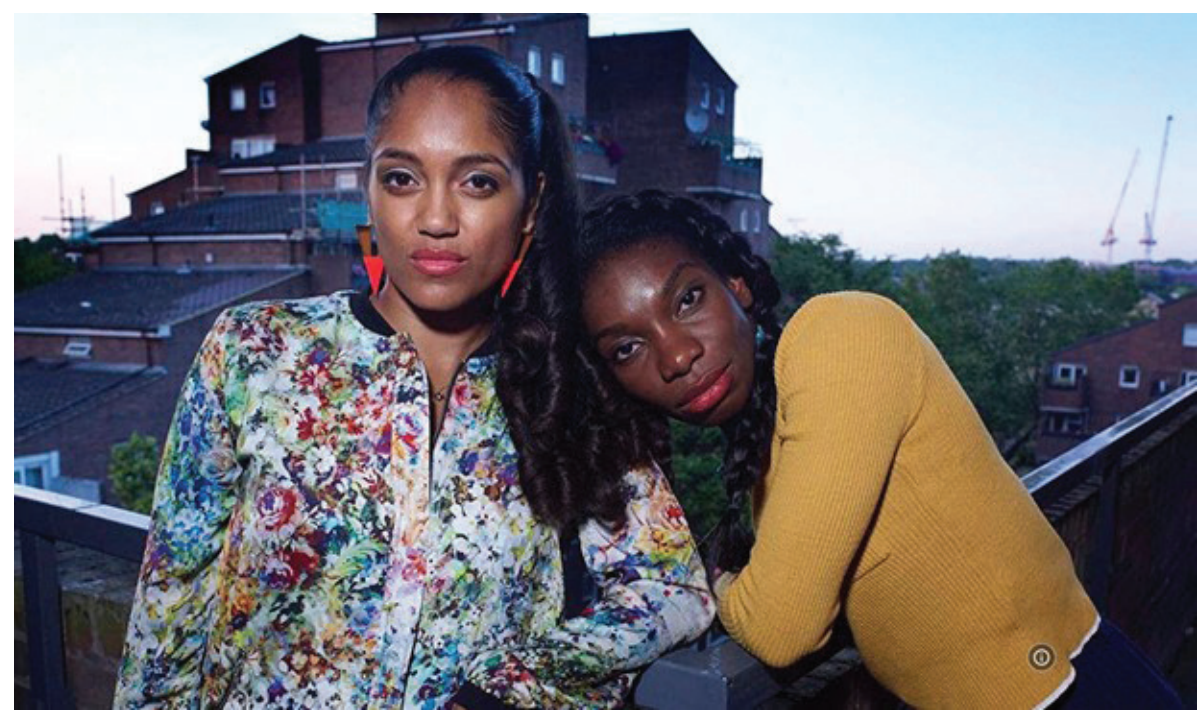

Figure 2. Tracey and Candice posed outside their housing community in a promotional image for Chewing Gum (Source: imdb.com).

Candice and Tracey's relationship is one built around sisterhood and a shared struggle of finding racial belonging in a community, and nation more broadly, that reinforces 'you can be either one or the other, black or British, but not both,' and adamantly clings onto notions of a post-racial and colour-blind society despite a dubious history of colonialism, and the nation's contemporary imperialist politics that disproportionately impact the global south. ${ }^{26}$ Connor's mother is emboldened to make these unfettered statements on blackness in front of Candice and Tracey because she does not view them as Black women or women of color, but British. Moreover, Candice and Tracey's collective processing and response to racist events throughout the show is a clear engagement with the construction of Black/blackness in the U.K. and the history of early Black British feminist movements.

As waves of Asian and African immigrants arrived in Britain following World War II, many of them were met with anti-immigrant sentiment and racism. While they were often lumped together and referred to as "coloured" or racial slurs, "Black" was adopted as a political identity to create a "shared space of marginalization" and collective naming for non-white British folks that were united in their new experience as post-colonial migrants. ${ }^{27}$ Thus, Black was much more of a racially inclusive term than how it is deployed in the U.S. or even in the U.K. today. Black in this context spoke to a shared racial consciousness that prioritized unity in response to racism, discrimination, and far-right violence African and Asian immigrants were confronted with in this new country. This conception of blackness also informed Black British feminist movements, organizing, and writings of the era. With early Black British feminist organizations, like the Organization of Women of African and Asian Descent, stressing the need for Afro-Asian unity, Black and Asian women in Britain conceived of themselves within a similar political landscape and both were integral to the development of Black British feminism. ${ }^{28}$ What often united Black British feminist voices, whether they were of African or Asian descent, was their marginalization within the British workforce and workplace discrimination, education and housing access, critiques of post-colonial capitalism and its implications on African and Asian countries, and yearning to create their own space within the growing field and overall movement of Black feminism.

While British racial formation and Black British feminism have used Black as an all-inclusive racial identifier and political framework, Coel engages some of these themes of Afro-Asian unity and political blackness through Candice and Tracey's relationship. Both characters are racialized alongside each other. They have similar upbringings in being raised in single-parent working-class households, and are routinely left to respond to their white peers and neighbor's racist pronouncements, like the example above, or Connor noting that Tracey looked 
like a "modern liberated slave" when they first met. Beyond this shared racialization, there is also a very clear distinction made between Candice and Tracey. While they are both visibly darker than most of the other women in the show, aside from Tracey's mother and sister, Candice is still seen as more sexually desirable because she has long straight hair, is mixed-race, and has lighter skin than Tracey. Conversely, Tracey is seen as less desirable to male characters, and is described by her friends as "niche" and beautiful "in a Whoopi Goldberg in The Color Purple," kind of way - a subtle jab that reaffirms Tracey's physical undesirability because of her darker skin and for lacking Candice's proximity to whiteness. ${ }^{29}$ This distinction is also very apparent when Candice and Tracey are in social settings, like parties, as Candice is readily granted access to exclusive events, and is frequently approached by men, especially Black men. Meanwhile Tracey's experience is the complete opposite. She is often subjected to disparaging comments about her appearance by the same Black men that find Candice attractive. This exploration of colorism in Chewing Gum is necessary as it begins to unpack some of the critiques of political blackness, primarily its inability to truly grapple with anti-blackness, misogynoir, and the specific experiences of people of African descent. Overall, Coel's intricate crafting of Tracey and Candice as sisters in struggle, while still attending to the very real identity politics which render their experiences navigating racism and misogynoir distinct, is certainly in stride with the shifting articulations of Black British feminism that seek to recognize this sameness and difference while working to build solidarity across racial lines. ${ }^{30}$

\section{Black Girl Surrealism}

In addition to Tracey and Candice's relationship, misogynoir, Black womanhood, and the intersection of race, class, and gender are most explicitly explored in Chewing Gum through Coel's coupling of Afrosurrealism and dark humor, or what I call, Black girl surrealism. Over the last five years Black American film and television writers, like Boots Riley, Terence Nance, and Donald Glover, have employed Afro-surrealism as a cultural aesthetic in their projects to call attention to the absurdity of racism and racial capitalism in society primarily through satire, horror, and portraying black life as something wholly disturbing. ${ }^{31}$ The cultural aesthetic has its roots in the Négritude Movement and work of artists, like Aimé Césaire, a Martinique-born poet, who drew on the French language and surrealism to critique life under colonialism. Césaire's surrealist imagination marked Discourse on Colonialism, a long form poem/essay that vividly articulated the impact of colonization on the colonized. In a 1967 interview recorded at the Cultural Congress of Havana, Césaire reflected on how the aesthetic and use of the French language influenced and shaped the unorthodox structure of his work, remarking, surrealism provided a "liberating factor." Césaire's use of surrealism helped catapult the Négritude movement and inspired a host of contemporaries, including Léopold Senghor, JeanPaul Sartre, Henry Dumas, and later Black Power artists like Amiri Baraka, who used their art, primarily poetry, short stories, and prose, to critique colonialism, imperialism, and systemic racism. Baraka coined the term Afro-surrealism and defined the cultural aesthetic in his introduction to Dumas's 1974 collection, Ark of Bones and Other Stories. Baraka described Afro-surrealism and Dumas's creative zeal as a "skill at creating an entirely different world organically connected to this one... But they were also stories of real life, now or whenever, constructed in weirdness and poetry in which the contemporaneity of essential themes is clear." 32

In recent years, Afrosurrealism has completely reshaped Black television and film with projects like Get Out (2017), Sorry to Bother You (2018), Atlanta (2016-), and Random Acts of Flyness (2018-), that enact Dumas's skill of creating new worlds constructed in weirdness and horror to reflect Black life in the U.S., primarily engaging themes around police brutality and the \#blacklivesmatter movement, gentrification and displacement, and Afropessimism. Furthermore, each of these works focused on Black millennial masculinity in their use of Afrosurrealism. While Chewing Gum takes place in present-day London, the absurdity of Tracey and her friends and neighbors helps suspend the show's reality, constructing a new world, like Dumas', where audiences peer deeply into Black girlhood and are forced to sit with the discomfort, albeit comedic, of whiteness, racism, misogynoir and the Black British experience. 
As a first-generation Ghanaian immigrant living in Britain, Coel's form of comedy and satire, which can best be described as cringeworthy, crass, and irreverent, leaves viewers laughing at Tracey's zany antics and self-reflexive comments at one moment, disturbed at the ease in which the white characters direct racist diatribes and comments at the characters of color at the other, and left agonizing over most characters' eroticism, questionable sexual behaviors and hygiene. Her Afrosurrealist aesthetic is very much informed by British dark humor. This roller coaster of comedic relief is an integral part of the structure and draw to British dark humor. ${ }^{33}$ Coel's use of British dark humor allows viewers to see the show as a product of both Black and British cultural production, provides an entry for white British viewers to engage in the show's themes and satirical world that has been constructed as a critique of whiteness and the absurdity of racism, and also showcases the intimacies of postcolonial Black British life. Similar to Négritude artists' command of the French language to cast the ills of colonialism, Coel's use of British dark humor in effect uses the 'masters tools,' in a cultural form to help unsettle notions of a 'post-racial' British society.

The most distinguishable element of Coel's use of Afrosurrealism is her performance of Black girlhood and womanhood. While Chewing Gum draws extensively from Coel's lived experience, the show overall has been praised by Black women in the U.K. for its relatability. Black British women viewers have specifically remarked on 'seeing themselves' in Tracey. From her background as a British-born African, struggles with reconciling Christianity and her sexuality, public housing community upbringing, fearlessness and tenacity, to her navigating colourism, racism, and interracial dating, many of Tracey's characteristics reflect a broader working-class Black British millennial woman experience. ${ }^{34}$ Furthermore, Coel's use of self-reflexivity throughout the show serves as an integral tool to explore Tracey's subconscious and has produced rich monologues that offer very specific commentary on navigating Black womanhood.

Each episode of Chewing Gum opens with Tracey breaking the fourth wall and delivering one of the aforementioned monologues. In the opening scene of season one episode three, Tracey is sitting on a bench in front of her public housing estate lamenting,

If I had $£ 1000$ l'd buy Brazilian yaky hair like [Be]yoncé, lip reduction, red velvet cupcakes, probably a dust pan and brush through this place. I mean look at it, its boring. It's not even crime. Like some fake ass estate. Like diet cola, it's diluted. Just forget the dust pan. l'd buy a train ticket and get out. Yeah, because I'm trying to do something worthwhile while I'm alive. Know what I mean? And these brick walls are dragging me back, man. I'm like a rose trying to grow out of mud. I was born a big thinker. I'm very wise. You know my mind is bare agile. I'm fast. You know what I mean? I got my ear to the ground so I'm alert at all times. I ain't even being vain. I just am... special.

Meanwhile, in the background Candice, Ola, and several of Tracey's white neighbors are orchestrating their own crime. Within ninety seconds the group nabs several bags from a vacant flat. To their surprise, the bags are filled with sex toys, not drugs. Tracey's monologue lays clear that her life's ambitions and goals far exceed her surroundings. She starts by relishing her own Black girl aspirations and material pleasures-buying an expensive weave and having cosmetic surgery. Tracey's constant yearning to alter her physical appearance reminds the audience that despite the veneer of confidence, Tracey still struggles with navigating misogynoir and reconciling her own internalized anti-blackness as a Black woman. Conversely, she positions herself as extraordinary, or "bare agile," recognizing that she's deserving of more, and that her living conditions are stifling her personal growth. But Tracey doesn't solely maintain contempt for her home as she simultaneously dispels many of the preconceived notions about public housing that are often used in response to racial and class demographics. While full of spirited and batty characters, Tracey's community is far from being a blighted and dilapidated housing estate, but a vibrant community of interdependent neighbors working collectively to survive, including during their hilarious heist of dildos. Many of Tracey's monologues throughout the show take a similar tone - aspirational, critical of her positionality as it relates to race, class, and gender, mixed with slapstick punchlines that often speak specifically to her experience navigating Black womanhood. 


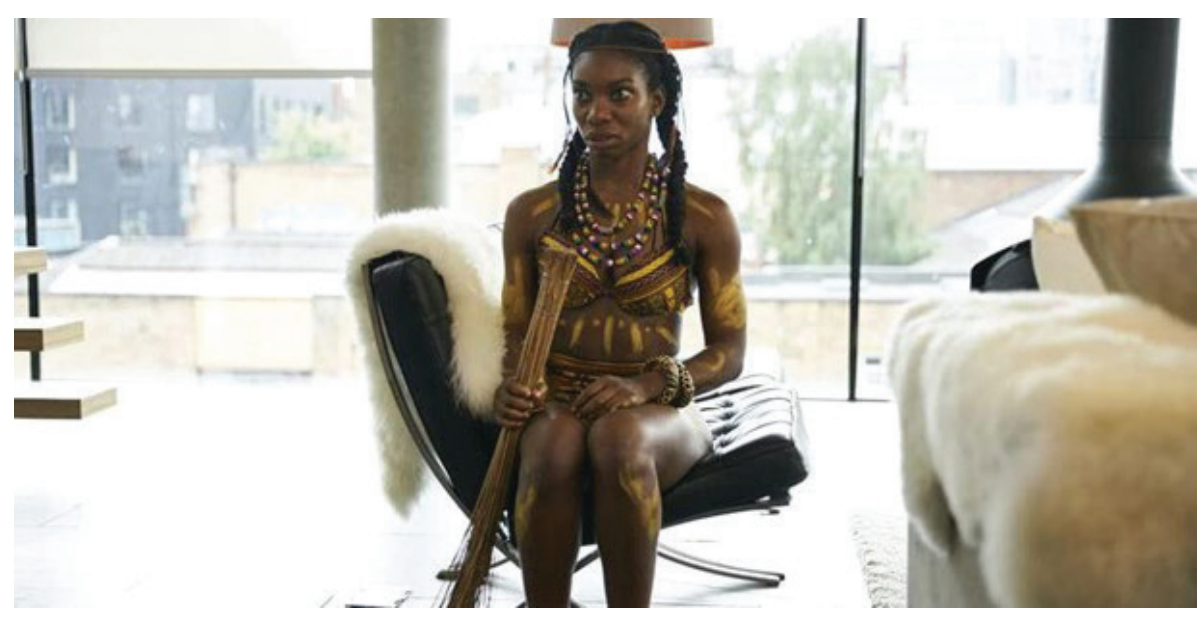

Figure 3. Season two episode two of Chewing Gum. Tracey has dressed up in "African tribal wear" to indulge the fetishization of her new suitor, Ashley (Source: imdb.com).

The use of self-reflexive monologues is also common in Issa Rae's Insecure and Radha Blank's film, The Forty-Year Old Version (2020), both of which are comedies and evoke Black girl surrealism. Issa Rae, who also serves as writer, creator, and producer for her show, Insecure, plays the lead character (also named Issa). Like Chewing Gum, Insecure is also an exploration of Black womanhood, this time set in rapidly gentrifying Los Angeles, California. As Issa navigates dating, working at a predominately white non-profit organization, and balancing tumultuous friendships, she often seeks release, therapy, and advice for herself. Throughout the show's first four seasons, Issa frequently retreats to her apartment bathroom during moments of turmoil and reflection. While standing in front of her mirror she awkwardly raps her pain, excitement, and/or anxiety, and at times her reflection in the mirror, representing her subconscious, will respond. In The Forty-Year Old Version, Radha Blank also uses rap and self-reflexivity to process her fear of approaching middle-aged Black womanhood. Film scholar, Faye Woods, describes these scenes and the use of self-reflexivity as "direct address" - a "blend of directness and distance to different ends" where audiences are drawn "uncomfortably close" to protagonists, often the "precarious girl," resulting in a form of comedy that functions like a deeply intimate portrait. ${ }^{35}$ While these moments of self-reflection are often satirical and loaded with punch-lines, they also intimately engage different facets of Black girlhood and womanhood, providing a more nuanced lens to help frame the show.

Coel's use of satire and British dark humor, coupled with self-reflexive monologues and engagement with Black feminism, serve as the anchoring elements of Black girl surrealism. However, it is the styling, costuming, and Black girl visual aesthetic of the show that helps animate these elements and articulate a cohesive vision of Black girl surrealism. Overall, much of the costuming for Chewing Gum is constructed around loud prints and vibrant colors. This over-the-top styling manifests in most of the show's characters as a form of creative class rebellion and expression. While the working-class characters, both Black and white, are unable to escape their modest housing estate, it is through their wardrobes that they live out all their posh fantasies. Expensive street wear and sneakers, faux furs, big hoops and gaudy jewelry are often part of the cast's styling, and clearly draw from Black girl style aesthetics. This faux-luxurious aesthetic intentionally comes across to viewers as kitsch and cheap, yet is filled with adornments, like Candice's signature hoop earrings and bomber jackets, Ola's colorful headwraps, and Cynthia's curly afro, that are a nod to Black girlhood. As mentioned earlier, Tracey's style is fairly consistent throughout the show. Her minimalistic hair and makeup are often paired with a skirt and bright colored top or patterned jumper, as if she were an adolescent schoolgirl. Tracey's appearance is often a stark contrast to her peers, this allows for her physical features to stand out, without her being hyper-sexualized. Furthermore, Tracey's schoolgirl appearance is part of the surrealist element, in that her wardrobe is a stark illogical juxtaposition to her reality. However, in a number of episodes Tracey's style is much more pronounced and ostentatious-an extension of the show's satire - as she attempts to achieve a 
"Beyoncé" or "tribal" look in an effort to attract male suitors. During season two episode two, Tracey is seen wearing poorly crafted and styled "African tribal wear" - beads, body paint, a small feather hair piece, and an earth-tone printed bikini bathing suit - with the hope of impressing her new suitor, Ashley. As she simulates African dance movements in her outfit, Tracey is overtly performing for the white gaze, represented by Ashley - a white man that has a fetish for Black women and is sexually aroused by stereotypical (e.g. tribal) images of Black women. This scene exemplifies Tracey's performance of Black beauty and style through the cursory lens of whiteness. Conversely, this scene, as well as the previous scene where she is dressed to look like Beyoncé, utilize Black girl surrealism to critique the absurdity of white beauty standards, challenge the politics of desirability, and critically engage with discourses on Black women and beauty.

Chewing Gum builds on Afrosurrealism by reframing the cultural aesthetic to center the narratives of Black women and girls. The show's use of British dark humor and satire, self-reflexive monologuing, and a Black girl aesthetic backdrop and styling, help shape the show's production of Black girl surrealism. It is through the lens of Black girl surrealism that Coel is able to critically interrogate the intersections of race, class, and gender, and offer a postcolonial critique of racism and whiteness in the U.K. Beyond Coel's work, Black girl surrealism will prove to be a useful term and framework for describing a growing body of Afrosurrealist Black women created and/or centered projects, from Insecure and The Fourty-Year Old Version, to Justin Simien's Bad Hair (2020).

\section{Conclusion}

After two seasons, Coel decided to end Chewing Gum in 2017. It was initially reported that she struggled to find other writers that "gelled with her comedic sensibility." ${ }^{36}$ During her 2018 MacTaggart lecture, Coel revealed that she had been sexually assaulted while working on the second season of the show, a traumatizing event that drew her away from the show, and served as an inspiration for her 2020 Home Box Office (HBO) series, I May Destroy You. Since the series finale of Chewing Gum, Coel has continued to act, write, direct and produce for several major television series and films, including Black Earth Rising (2018), Star Wars VIII: The Last Jedi (2017), and Black Mirror (2011-2019). I May Destroy You is Coel's most audacious and intimate project yet, and continues to peel back layers of the Black British experience. With her own narrative of sexual assault serving as an inspiration for the show, Coel explores the aftermath of surviving such a traumatizing experience as a Black woman working in media and entertainment. Throughout the season, Coel's character, Arabella, spirals out of control, wrestles with substance abuse, depression and other mental health disorders, and attempts to find a source of healing through her friendships, writing, and vengeance. The show also explores Black queer identity and sexual assault within the gay community.

Despite Black British actresses limited access to dynamic roles in the U.K., they are making their mark in Hollywood. Michaela Coel has created work for her Black peers in Britain, while also ensuring that race and the Black British experience are reflected in European television. In just five years she has written, produced, directed, and starred in two major U.K.-based television series that have helped dispel notions of colour-blindness in Britain through their vivid exploration of the Black British experience. Coel's ode to Black British feminism and Black girlhood, Chewing Gum, has helped usher in a new age of storytelling.

\section{Notes}

1. Following April Reign's use of \#oscarssowhite, \#representationmatters also emerged as a hashtag to challenge the lack of diversity in film and entertainment, as well as other industries and sectors, including, academia, healthcare, and electoral politics. The hashtag turned cultural movement aimed to provide children with more diverse and positive representations of historically marginalized people, including African Americans, Asian Americans, LGBT folks, and those with disabilities, occupying positions of power and/or holding positions or roles that they have been historically denied access to. 
2. Brit Dawson, "Michaela Coel shares stories of racist incidents on set of Chewing Gum," Dazed Digital, July 7, 2020, https://www.dazeddigital.com/film-tv/article/49736/1/michaela-coel-shares-stories-of-racist-incidents-on-set-ofchewing-gum

3. Ibid.

4. As quoted in Stephen Bourne, Black in the British Frame: The Black Experience in British Film and Television (London: Continuum, 2001), 142.

5. Ibid

6. Mark Brown, "Roles in UK for black and minority ethnic actors worse than ever, claims David Oyelowo," The Guardian, September 28, 2015 https://www.theguardian.com/film/2015/sep/28/roles-uk-black-minority-ethnic-actors-worse-thanever-claims-david-oyelowo

7. Leo Barraclough, "Proposals for Increasing Diversity in British Television Delivered to Government, Industry Leaders," Variety, June 19, 2020, https://variety.com/2020/tv/global/diversity-british-television-1234642630/

8. BAME is used as an acronym in the U.K. to describe racial and ethnic minorities, it stands for "Black and Minority Ethnic."

9. Barraclough, "Proposals for Increasing."

10. British Film Institute, BFI Television Handbook (London, U.K.: British Film Institute, 2004), 58.

11. BBC News, "BBC commits £100m to increasing diversity on TV," BBC News, June 22, 2020.

12. Christine Geraghty, "Casting for the Public Good: BAME Casting in British Film and Television in the 2010s," Adaptation 14, no 2 (2021): 2 .

13. Ibid.: 16.

14. "Chewing Gum Dreams" video, 4:08, YouTube, posted by Yard Theatre, September 1, 2013, https://www.youtube.com/ watch?v=EFuk3gUDJBY

15. See: Keeanga-Yamahtta Taylor, ed., How We Get Free: Black Feminism and the Combahee River Collective (Chicago: Haymarket Books, 2017).

16. Shoniqua Roach, "Black pussy power: Performing acts of black eroticism in Pam Grier's Blaxploitation films," Feminist Theory 19, no. 1 (2018): 10.

17. Joan Morgan, When Chickenheads Come Home to Roost: A Hip-Hop Feminist Breaks It Down (New York: Simon \& Schuster, 2000), 55-59.

18. Patricia Hill Collins, Black Sexual Politics: African Americans, Gender, and the New Racism (New York: Routledge, 2004$), 121$.

19. Francesca Sobande, "Awkward Black girls and post-feminist possibilities: Representing millennial Black women on television in Chewing Gum and Insecure," Critical Studies in Television 14, no. 4 (2019): 435-450.

20. Yael Levy, "A Sexual Subject: Black women's sexuality in Insecure," Feminist Media Studies, published online before print, February 2020.

21. Moya Bailey and Trudy, "On misogynoir: citation, erasure, and plagiarism," Feminist Media Studies 18, no 4 (2018): $762-763$.

22. Jeannine Amber, "Authentic Beauty Michaela Coel Isn't Waiting for Permission," Essence, April 18, 2019, https://www. essence.com/feature/michaela-coel-isnt-waiting-for-permission/

23. See: Maxine Leeds Craig, Ain't I a Beauty Queen?: Black Women, Beauty, and the Politics of Race (Oxford: Oxford University Press, 2002).

24. See: Imani Cheers, The Evolution of Black Women in Television: Mammies, Matriarchs and Mistresses (New York: Routledge, 2017); Marie Gammage, Representations of Black Women in the Media: The Damnation of Black Womanhood (New York: Routledge, 2015)

25. Cheers, The Evolution of Black Women in Television, 5-6.

26. Heidi Safia Mirza, ed., Black British Feminism: A Reader (New York: Routledge, 1997), 3.

27. Ibid.

28. See Amrit Wilson, Finding a Voice: Asian Women in Britain (London: Virago, 1978).

29. Christabel Nsiah-Buadi, “In 'Chewing Gum,' Tracey Is The Quirkiest And Freest Character On TV,” NPR, April 24, 2017, https:// www.npr.org/sections/codeswitch/2017/04/24/515228121/in-chewing-gum-tracy-is-the-quirkiest-and-freest-character-on-tv

30. Heidi Safia Mirza, "Harvesting our collective intelligence: Black British feminism in post-race times," Women's Studies International Forum 51, (2015): 1-9.

31. Eric Forthun, "We should be addressing whiteness less, and affirming blackness more: Random Acts of Flyness, Afrosurrealism, and Quality Programming," Communication, Culture \& Critique 14, no 1 (2021): 3.

32. Amiri Baraka, "Henry Dumas: Afro-Surreal Expressionist," Black American Literature Forum 22, no. 2 (Summer 1988 ): 164.

33. I define British dark humor as modern satire that largely draws upon violent and traumatic events, as well as self-deprecation. British dark humor is both horrifying and humorous. It is surreal, irreverent, and often ludicrous.

34. Sobande, "Awkward Black": 439-441.

35. Faye Woods, "Too Close for Comfort: Direct Address and the Affective Pull of the Confessional Comic Woman in Chewing Gum and Fleabag," Communication, Culture and Critique 12, no. 2 (2019): 194-197.

36. Yohana Desta, "Goodbye to Michaela Coel's Chewing Gum, a Rare Burst of Joy," Vanity Fair, August 22, 2017, https://www. vanityfair.com/hollywood/2017/08/chewing-gum-third-season 


\section{B i o graph y}

Jeanelle K. Hope is an Assistant Professor of Comparative Race and Ethnic Studies at Texas Christian University. She is currently developing a book manuscript on Afro-Asian solidarity in the post-Civil Rights era. Hope's broader research interests include: Afro-Asian studies, Blacks in the West, Black girlhood, Black art and cultural production, and transnational feminism. Her work has been featured in the American Studies Journal, Amerasia Journal, Essence, and Voices of River City. 